\title{
Career development and employee commitment in industrial organisations in Calabar, Nigeria
}

\author{
Agba, A. M. Ogaboh (PhD) ${ }^{1}$; Festus Nkpoyen (PhD) ${ }^{2}$; Ushie, E. M. (PhD) ${ }^{3}$ \\ Department of Sociology, University of Calabar, Calabar, Nigeria
}

\begin{abstract}
This study examined the relationship between career development and employee commitment in industrial organizations, in Calabar, Cross River State, Nigeria. Niger Mills PLC, Calabar and Cross River Newspaper Corporation, Calabar were selected for the study. Data was obtained through structured questionnaire. Three hypotheses were tested using Pearson Product Moment Correlation ( $r$ ). Findings revealed that, career advancement, career counseling and career opportunities significantly influence workers commitment. The study recommended among others that, a comprehensive career development programme should be adopted by management.
\end{abstract}

Keywords: Career development, employee commitment, industrial organizations.

\section{INTRODUCTION}

Workers in contemporary society are expressing a strong desire to pursue more than just a job. They are looking for employment opportunities that promise an extension of their interests, personality and abilities. Then want a variety of things from their jobs besides a pay cheque and a few fringe benefits, and their loyalty to the organization depends upon the degree to which their employer satisfies these wants (Kent \& Otte, 1982, Agba, 2004). With improved living standards, workers are no longer satisfied to have just a job and the usual fringe benefits. They want a career that expresses their interests, personality, abilities and that harmonizes with their total life situation. Unfortunately, most employers have failed to recognize this need, and the tools and experiences they provide do not enable workers to develop in their career.

High salaries, good working conditions, health and dental insurance, retirement plans, stock purchase programmes, reduced work hours, technological advancement, educational reimbursement programmes among others might seem to be the necessary ingredients for individual happiness and fulfillment in the world of work. Despite these benefits, there are many employees at all levels that appear to be dissatisfied and delusion with themselves, their work and their future. Most workers realize that in any organizational setting, they must have opportunities for continuing growth and advancement if they are to be satisfied. Where the employer can provide the worker with these opportunities, a proper attitude of loyalty and satisfaction can be developed and performance enhanced.
In the past, the word "work" often had a negative connotation, implying something that was done for economic survival and was not expected to provide personal employment. Most workers today are looking for a career that means something more than just a job with the usual fringe benefits. This therefore poses the following research questions why are employees complaining despite the fact that the work environment is so conducive? How is management able to appreciate the necessity to understand human development and to establish a new definition of work situation? To what extent does management show interest in the career development of its employees? In view of these questions, this study is designed to examine the relationship between career development variables such as career opportunities, career advancement, career counseling and employee commitment in Niger Mills PLC, Calabar, Nigeria.

Study Area: Calabar is the capital of Cross River State, Nigeria. Calabar is historically the settlement of the Efiks, Quas and Efut (Effiong-Fuller, 1996). Economically, Calabar is a seaport, an airport town, a market for agricultural produce from the hinterlands, and a home of many industries, including Niger Mills PLC Calabar and Cross River Newspaper Corporation where this study is conducted. With the trend of political and economic development in Calabar, the city today is a cosmopolitan society with migrant from diverse cultural backgrounds. The migrant population includes the Hausas, Yorubas, Igbo, Ibibio, Annang, Yakurr, Utugwang, etc. The population of Calabar is estimated at 328,877 with a density of 980 person per square kilometer (National Population Commission, 2006). 
Am. J. Sci. Ind. Res., 2010, 1(2): 105-114

Niger Mills PLC Calabar is situated at Ikot Eka Edem along Murtala Muhammed Highway Calabar. It was established in 1967 with an authorized share capital of 400,000. The Company's major produce are wheat flour and poultry feed. Niger Mills PLC is headed by a chairman and Board of Directors. The board is the policy-making body; and it consists of a Chairman and seven other members. The General Manager is the chief executive of the company and is responsible for the execution of the policies of the board. Other senior personnel include - the secretary, personnel manager, chair accountant, chief miller, technical manager and sales manager.

Cross River Newspaper Corporation, Calabar was established by the Cross Rive State Government, Nigeria to enhance the dissemination of information in the state and its immediate borders. The company is situated at Barrack Road, Calabar, Cross River State. The company has staff strength of 224 workers spread across eight departments. The company's functions include among others information dissemination, progamme coverage, enlightenment/educative programmes and commercial activities. The company's board members are responsible for policies formulation while the executives ensure letter-to-letter implementation of board policies. The company also consists of junior staff who responsible for the grassroot implementation of the establishment's policies/goals. This study covers all these categories of staff in the company except board members.

\section{Literature and Empirical Review:}

Career Development: Career development involves concerted efforts directed towards assessing a workers' potentials identifying likely career paths for that employee and designing and implementing "various forms of training and experience to prepare that person for more advanced job". When a firm takes on career development as a human resource function, such activity is called career guidance, which is composed of three sub-processes or steps: forecasting, planning and counseling. The first step is to identify the usual path of promotion (career ladder) within the organization. The second step is to estimate when and where job opening will occur and to identify liking candidates for these openings. Forecasting is an integral part of manpower planning. The likely candidates are assessed to determine their existing skills and these skills are compared with those required for the job. Training may then be planned to correct any skill deficiencies that are identified through this comparison (Peterson \& Tracey, 1979).

Career development has both personal and organizational dimensions. In organizational level, it is a planned programme designed to match individual and organizational needs. Examples of such programmes include - recruitment policy that encourages a full exchange of information between the applicant and the company prior to hiring; a promotion policy that considers the needs and objective of both the organization and the employee. A personal level career development allows for the changes in individuals as their work roles overlap with their social and family development. At this level, the employee and his family and their needs must be reckoned with by employers if they are to be successful in developing and hanging onto good employees. Workers want management to show interest in their career development, which would lead to increased productivity and greater commitment to organizational goals.

In most industrial organizations, effort at career guidance are directed towards organizational goals, thus, each employee should take some initiative in planning his or her own career. Since, not all firms accept the responsibility for retraining employee when job technology changes, the worker must be aware of the potential for change in any career he or she undertakes (Peterson \& Tracey, 1979).

It takes a professional manager to realize that time spent in career counseling may have a greater pay off in the employee's performance than time spent on routine day-to-day responsibilities. Employee must assume primary responsibility for his or her career development since the company cannot develop a worker who does not wish to be developed. While the employee does have primary responsibility for personal development, the manager and human resources development have interrelated roles in the career counseling process. Dual commitment from the employee and the organization is required if the career counseling process is to be effective. The role of the manager is to encourage growth and create an environment that will also stimulate and encourage growth. The role of the human resource department is to help both the manager and subordinate consider potential career routes, possible departmental needs and available resources for meeting these needs (Gambill, 1979).

Career development is given least attention by most organizations. It is therefore pertinent that 
Am. J. Sci. Ind. Res., 2010, 1(2): 105-114

organizations accept and legitimize the workers needs for career growth (Leach, 1977). Career problems are unique to the individual worker. Organizations can make serious human resources planning mistakes if it assumes that all people share the same career notions and intentions. This career intention surveys, career information packages and career support systems in organizations to meet employee expectations in imperative (Leach, 1980).

In most firms, it is becoming increasingly evident that career management programmes are cost justified in the same terms as staffing programmes; that is each approval contributes to improved utilization of employees and overall organizational effectiveness (Leach, 1980). Thus, the purpose of career development is to match an employee's career aspirations with opportunities and challenges available within the organization (Aplin \& Gerster, 1978). The interest of career development also entails a successful placement of employees in positions that meet their needs as well as the organization's needs. Therefore, employee career must be of concern to organizations and managers in order that human resources may be developed to meet constantly changing environmental condition (Aplin \& Gerster, 1978; Flippo, 1980).

Organizational Commitment: Organizational commitment is describe as a more active and positive orientation toward the organization (Porter, William \& Smith, 1976). It is an "attitude or orientation toward the organization which links or attaches the individual or worker to the establishment. It entails a process whereby the goals of the individual or worker is increasingly integrates with that of the organization (Hall \& Schneider, 1972).Organizational commitment deals with workers identification with and involvement in a particular establishment (Becker, 1980). It entails three components - workers' readiness to exert effort on behalf of the organization; workers' acceptance of organizational goals and values; and workers desires to remain with the organization. (Cool \& Wall, 1980). Organizational commitment can also be view as an outcome of inducement/contribution transactions between the establishment and workers (Stevens et al, 1978).

The highly committed worker takes his or her work seriously. The allegiance of the highly committed worker resides with the organization, not the job or work (Dipboye, et al 1994). There are personal dangers of over commitment to the organization; such worker (the organization man) identifies totally with his/her work group or organization that he/she substituted the establishment's goals and beliefs for his own. That is, the over committed worker submerged his own identity for the good of the organization (Mowday, Richard, Steer \& Porter 1979). According to Lawler \& Shuttle (1973) and Romzek (1989) over commitment is desirable, particularly for the organization. This is because over commitment may not be a zero-sum game (either all good or all bad).

There are different dimensions of organizational commitment. The most commonly measured dimension is affective or attitudinal, that is, an emotional attachment to and involvement and identification with the organization. The second dimension labeled continuance commitment refers to the perceived cost associated with leaving the organization, such as giving up pension plans and profit sharing (Becker, 1980); Heibiniak \& Alutto, 1972). Affective commitment correlate positively with job performance and continuance commitment correlate negatively with job performance. Committed workers are less likely to be absent from or quit their jobs compared with their less committed colleagues (Meyer et al, 1989, Williams, 1978).

There is also a causal relationship between organizational commitment with job satisfaction. The assumption here is that organizational commitment is a determinant of job satisfaction or vice versa. In other words, satisfaction and commitment are reciprocally related. Increased satisfaction caused increased commitment and, in turn, increase commitment caused further increase in satisfaction (Steers, 1977a; Reichers, 1985). Workers' commitment to organization is also a function of their perception of the organization's commitment to them (Randal, 1987).

\section{Career Development and Organizational} Commitment: Employee career effectiveness is directly related to organizational effectiveness and that career planning activities can lead to a more committed work force (Hall, 1976).Similarly Stevens et al (1978), opined that too much time in one position may be perceived as career stagnation and have an adverse effect on commitment. Kanter (1980), group workers in formal organizations into two major categories: "the moving" versus "the struck". These two groups of people behave differently and have many difference attitudes towards their jobs. Being "Stuck" (that is lacking opportunity) has a number of adverse effects, firstly, it leads to low aspirations; since "the stuck" cannot realistically expect to advance very far, they trim 
their aspirations to suit the reality. Secondly, "stuck" self esteem is diminished; they are no longer willing to take the risks or to use all their skills and competences. Thirdly, "the stuck" becomes disengaged from their work, a condition that leads to high turnover in jobs. Fourthly, "stuckness" affects cordial relationship within the organization. "The stuck" lose sight of the big organizational picture and instead form cliques to protect their dignity.

The interaction or "fit" of employees' with their work situation also determine their job involvement and organizational commitment (Rabinowitz, 1981; Ferri \& Aranya, 1983). Similarly, Satump and Hartman (1984) assert that higher perceived person-job congruence was positively related to organizational commitment. Angel \& Perry (1981), observed that a worker's higher order needs significantly relates to organizational commitment. Steers (1977b), Verderber, Green and Baugh (1981) found significant positive relationship between perceived job characteristics and organizational commitment.

Other investigations have also supported the proposition that there is a relationship between career-based variables and propensity to remain, which is an aspect of organizational commitment. Hrebiniak and Alutto (1972) maintain that there is a positive relationship job between satisfaction, advancement and propensity to turnover. There is also a negative relationship between perceptions of upward mobility and the propensity to leave among a service-oriented business organization.

Another variable related to but distinct from job satisfaction; job involvement, and organizational commitment is professional or career commitment. Career commitment is form of work commitment defined as identification with and involvement in one's profession, such as teaching, nursing, or engineering. General studies had demonstrated that professional commitment is empirically independent of both job involvement and organizational commitment (Blau 1985, 1986; Morrow, Bowers \& Seashore, 1967). In addition, professional commitment has shown significant relation with turnover in a sample of bank workers and several other job related behaviours in a sample of accounts (Blau \& Boal 1987).

\section{Theoretical Consideration}

This study utilizes the following theories:

Trait and Factor Theory: Parsons (1909) the "father of guidance" proposed the trait and factor theory to explain the process of vocational choice. Parson' theory is predicated on the assumption that individuals differ as well as occupations, thus bringing into limelight the old adage of individual differences. The theory sets out to match people and occupations in respect of their abilities, interests, intelligence, attitude and aptitude. The theory also asserts that the individuals needs and values can only be fully realized when they are matched with those jobs which are relevant to such needs and values. To explain his views further, Parsons proposed the following as basic steps through which an individual goes in his attempt to choose a career: (i) A clear understanding of himself, his abilities, aptitudes, intersects, ambitions, resources, limitations and their causes.(ii) A good knowledge of the requirement and prospects in different jobs; and

(iii) A sound reasoning of the relationship between the above two groups of factors and selection of a good match. This theory therefore states that if an individual's personality is carefully observed, better prediction can be made about his career behaviour.

Tiedeman and O'hara Ego Identity Theory : David Tiedeman and Robert O'hara (1963) examined the process of career development as a part of a continuing process of differentiating ego identity. They contend that variables such as a person's early childhood experiences within his family, the psychological crises encountered at various developmental stages, the equilibrium between vocational goals, the individual needs and those of the society and the personality characteristics of an individual all have great impact on career development.

Tiedeman and O'hara emphasized that there is an intervention relationship between career and personality in organization, the former exerting significant influence on the later. In their view, career development is a process of modeling a career identity through differentiation and personality integration as one come across a work related problem. It is their conception that differentiation relates to the uniqueness which exists in the individuality and how he expresses his individuality. They conceive integration on the other hand as the ways in which the individual adjusts himself to accommodate others around him in order to become an integral part and an acceptable member of the society. In their opinion, the decision the individual makes in relations to his work, daily activities, form the basis and framework of his career development. Their theory places emphasis on the progressive 
developmental stages of career development with career decision being significant in the process.

\section{Exchange Approach to Organizational} Commitment : Steven et al (1978) argued in their approach that, attachments to the organizations are influenced strongly by "side-bets, accrued extrinsic benefits that would be lost if membership was terminated. Becker (1960) contends that commitments come into being when a worker, by making a side-bet, links extraneous interests with a consistent line of activity. When side bets are made to an organization example pension plans or other accrued investments, the worker perceive associated benefits are more likely to stay with that organization. The worker thus becomes organizationally committed. If other investments, such as time or identification, are made to an organization, the sidebets mechanism operates to produce occupational commitment.

The exchange approach is also exemplified by Kanter (1980), continuance commitment. In his discussion of what originations do to elicit members' commitment, he mentions the manipulation of the reward system to enhance continuance commitment. This coincides with Etzioni's (1975) "Calculative involvement". According to Kanter (1980) organizational strategies, which promote continuance commitment through sacrifice and investment sacrifice involves the giving up of something considered valuable or pleasurable in order to belong to the organization. Involvement here entails a process whereby the individual gains a stake in the organization, commits current and future profits to it so that he must continue to participate if he is going to realize them. Stevens et al (1978) contend that with its economic rationale, the exchange approach gives a general model for commitment that can be attached to various objects and that allows for variety of possible influence both positive and negative. Morris and Sherman (1981) assert that from the stand point of predicting ongoing behaviour in organizations, at least two limitations seem evident at the present time with measures of commitment that have been derived from the exchange approach. First, this approach, they argue, has generated measures of commitment that divides the concept as an orientation toward the organization that is predicted almost entirely on utilitarian considerations. Accordingly, the exchange perspective assumptions have yielded measures that tap particular instrumentalities that Etzioni (1975) identifies with calculative involvement" and a "low intensity" orientation towards the organisaiton.

Therefore, to the extent that side bets or other tenure-based accrued phenomena are seen as the principal determinants of economic levels, one is led to measures of commitment that may reflect the degree to which the member is hesitant to leave the organization for employment elsewhere (that is, organizational attachment or propensity to leave) but little else with respect to ongoing behavioural predispositions within the given employment relationship (Morris \& Sherman, 1981). It is consistent with this argument that measures developed under this approach have indexed commitment exclusively as the likelihood that respondents would leave the organization if certain inducements were available in other employment settings; although such measures may provide good information about a member's propensity to leave the organization. It is however difficult to suppose, a priori, that other ongoing behaviour would be predicted as well.

\section{METHODOLOGY}

Survey design was adopted in this study. It was adopted because of its economic vantage over other research designs; in that it allows the study of representative samples which permit inferences from the population that would be too expensive to study as a whole. The study was drawn from a population of six categories of employees of both sexes. The departments are Accounting, Engineering, Security, Administration, Marketing, and Production. Purposive and stratified random sampling methods were use to draw 530 respondents from Niger Mills PLC, Calabar and Cross River State Newspaper Corporation, Calabar, Nigeria.

Questionnaire and interview were used to gather data from respondents. The questionnaire consists of thirty items. The questionnaire is divided into three sections. The first consists of questions on the demographic characteristics of respondents. These enabled the researchers to elicit data from respondent on their years of service in the organization, rank or position held, length of time spent in present position, age, sex, marital status and education qualification. Section B, deals with career development inventory; consisting of items in career counseling, career opportunity and career advancement respectively. Questions were designed to elicit information from the respondents about the level of interest the organization shows in workers 
career development. Section C consists of items that elicit information on employee's commitment to the organization.

The study also used personal interview, the executive and management were interviewed. They were interviewed with the aid of predetermined questions. The interview elicits information that were not included in the questionnaire as well as facts that may be critical, such as information that management might consider quite private.

Table I: Demographic Characteristics of Respondents

\begin{tabular}{|c|c|c|}
\hline $\begin{array}{l}\text { Particulars of } \\
\text { respondents }\end{array}$ & Frequency & Percentage(\%) \\
\hline \multicolumn{3}{|l|}{ Rank } \\
\hline Executive & 106 & 20.00 \\
\hline Management & 115 & 29.25 \\
\hline Supervisor & 131 & 24.72 \\
\hline Junior & 138 & 26.04 \\
\hline Total & 530 & $100.00 \%$ \\
\hline \multicolumn{3}{|l|}{ Years of Service } \\
\hline $0-5$ & 205 & 38.68 \\
\hline $6-10$ & 163 & 30.76 \\
\hline $11-15$ & 81 & 15.28 \\
\hline 16 and above & 81 & 15.28 \\
\hline Total & 530 & $100.00 \%$ \\
\hline \multicolumn{3}{|l|}{ Age } \\
\hline $21-30$ & 180 & 33.96 \\
\hline $31-40$ & 187 & 35.28 \\
\hline $41-50$ & 123 & 23.21 \\
\hline $51-60$ & 40 & 7.55 \\
\hline Total & 530 & $100.00 \%$ \\
\hline \multicolumn{3}{|l|}{$\begin{array}{l}\text { Educational } \\
\text { Qualification }\end{array}$} \\
\hline B.Sc/HND & 163 & 30.75 \\
\hline $\begin{array}{l}\text { Professional } \\
\text { Degree }\end{array}$ & 123 & 23.21 \\
\hline $\begin{array}{l}\text { Post Graduate } \\
\text { Degree }\end{array}$ & 113 & 21.32 \\
\hline OND/NCE & 131 & 24.72 \\
\hline Total & 530 & $100.00 \%$ \\
\hline \multicolumn{3}{|l|}{ Sex } \\
\hline Male & 286 & 53.96 \\
\hline Female & 224 & 46.04 \\
\hline Total & 530 & $100.00 \%$ \\
\hline
\end{tabular}

Source: Field work 2010

The hypotheses postulated for this study acted as a guide in the process of data analysis. Pearson Product Moment Correlation Coefficient ( $r$ ) was calculated and used to ascertain the relationship between career development and organizational commitment. The result of the tested hypotheses formed the basis of research discussions.

\section{RESULTS}

Demographic data of respondents revealed majority of the respondents were males while 46.06 percent were females. Educational qualification of respondents shows that 30.75 percent were BSc/PND holders, 24.72 percent had OND/NCE, 23.21 were professional degree holders while 21.72 percent had post graduate degrees. Majority of the respondents were between the ages of 21-30 years while the least, that is 7.55 were 51 years and above. Most respondents had only served their organizations for 5 years. For further details see table 1 .

The first hypothesis sought to test whether there is a significant relationship between career advancement and employee commitment in Niger Mills PLC, Calabar and Cross River Newspaper Corporation, Calabar. In the analysis Pearson Product Moment Correlation Coefficient ( $r$ ) was used with career advancement score $\left(x_{1}\right)$ as the independent variable and employee commitment scores (y) as the dependent variable. The coefficient of correlation ( $r$ ) was applied and the result was 0.0 .974 , at 0.05 level of significance, 528 degree of freedom (see table 2). Since the coefficient of the correlation $(r)$ is 0.974 and is greater than the critical value $r=0.088$, it reveals that, there is a significant relationship between career advancement and employee commitment. This result supports the positions of Williams (1978), Crampson et al (1978), Flippo (1980), Kent and Otte (1982).

The third hypothesis tested the relation between career opportunities and employee commitment in Niger Mills PLC Calabar and Cross River State Newspaper Corporation, Calabar. In the analysis as depicted in table 4, Pearson Product Moment Correlation Coefficient ( $r$ ) was used with career opportunities score $\left(x_{3}\right)$ as the independent variable and employee commitment score $(y)$ as the dependent variable. The coefficient of correlation $(r)$ was applied and the result was 0.986 at 0.05 level of significance and 528 degree of freedom. Since the coefficient at correlation $(r)$ is 0.986 is greater than the critical value $r(0.088)$, it reveals that, there is a significant relationship between career opportunities and employee commitment. This finding corroborate the findings of Rabinowitz (1981), Ferri and Aranya (1983), Satump and Hartman (1984). 
Am. J. Sci. Ind. Res., 2010, 1(2): 105-114

Table 2: Relationship between Career Development and Employee Commitment to the Organization

\begin{tabular}{|l|l|l|l|l|}
\hline \multirow{2}{*}{ Variables } & $\sum \mathbf{x}$ & $\sum \mathbf{x}^{2}$ & \multirow{2}{*}{$\sum \mathbf{x y}$} & \multirow{2}{*}{ rxy } \\
\cline { 2 - 3 } & $\sum \mathbf{y}^{2}$ & $\sum \mathbf{y}^{2}$ & 17257 & 0.974 \\
\hline Career advancement $\left(\mathrm{x}_{1}\right)$ & 700 & 8352 & \multirow{2}{*}{} & \\
\hline Employee commitment $(\mathrm{y})$ & & & & \\
\hline
\end{tabular}

At 0.05 ; degree of freedom $=528$; critical $r=0.088$

Table 3: Relationship between Career Counseling and Employee Commitment to the Organization

\begin{tabular}{|l|l|l|l|l|}
\hline \multirow{2}{*}{ Variables } & $\sum \mathbf{x}$ & $\sum \mathbf{x}^{2}$ & \multirow{2}{*}{$\Sigma \mathbf{x y}$} & \multirow{2}{*}{$\mathbf{R x y}$} \\
\cline { 2 - 3 } & $\Sigma \mathbf{y}$ & $\Sigma \mathbf{y}^{2}$ & & \\
\hline Career counseling $\left(\mathrm{x}_{2}\right)$ & 818 & 11147 & 20091 & 0.982 \\
\hline Employee commitment $(\mathrm{y})$ & 1490 & 37372 & & \\
\hline
\end{tabular}

At 0.05 ; degree of freedom $=528$, critical $r=0.088$

Table 4: Relationship between Career Opportunities and Employee Commitment to the Organization.

\begin{tabular}{|l|l|l|l|l|}
\hline \multirow{2}{*}{ Variables } & $\sum \mathbf{x}$ & $\sum \mathbf{x}^{2}$ & \multirow{2}{*}{$\sum \mathbf{x y}$} & \multirow{2}{*}{$\mathbf{R x y}$} \\
\cline { 2 - 3 } & $\sum \mathrm{y}$ & $\sum \mathrm{y}^{2}$ & 24220 & 0.986 \\
\hline Career opportunities $\left(\mathrm{x}_{3}\right)$ & 988 & 16103 & & \\
\hline Employee commitment $(\mathrm{y})$ & 1490 & 37372 & & \\
\hline
\end{tabular}

At 0.05 ; degree of freedom $=528$, critical $r=0.088$

\section{Discussion of Findings}

Career Advancement and Employee Commitment: The coefficient of correlation ( $r$ ) of 0.284 as shown in table 2 indicated a positive relationship between career advancement and employee commitment. This finding harmonizes with the studies of Kent and Otte (1982), that, people want a variety of things from their jobs besides a pay check and a few fringe benefit and their loyalty to their organizations depends upon the degree to which employees satisfy their wants. They contend that employees want management to show an interest in their career development and once this is done, workers commitment to organizational goal increases. Also the finding agrees with the conclusion of Hrebiniak and Alutto (1972) that a positive relationship exists between satisfaction, job advancement and propensity to remain in the organization. The study supports Peterson and Tracy (1979) who observes career advancement as efforts directed at assessing a person's potential, identifying likely career paths for that person and planning and executing various forms of training and experience to prepare that person for more advanced job.

A possible explanation for the significant relation as offered by Kent and Otte (1982) is that career development presumes the legitimacy of employee needs at all levels and attempts to provide the best possible match with organizational needs. Leach
(1977) explains that organizations need to learn how to accept and legitimate the individuals need for career growth since people are beginning to seek greater self-determination and organizations of the future will no longer be able to indicate employee commitment.

According to Roe (1957) each individual inherits a tendency to expand his energies as much as possible in a particular way. The inherent tendency the individual possess to expand psychic energy in a particular manner, coupled with childhood experiences make up the way a person develops to satisfy his needs throughout his life time. Kanter (1980) observes that being "stuck" (that is lacking opportunity for advancement) has a number of adverse consequences; it leads to lowered aspirations; diminished self esteem; it disengaged employees from their work and it affects relationship, in that the stuck loses sight of the big organizational picture or goal.

Career Counseling and Employee Commitment: The coefficient of correlation ( $r$ ) of 0.264 as shown in Table 3 indicated a positive relationship between career counseling and employee commitment. This findings is in line with Roe's (1957) occupational development and choice. He views needs as unconscious motivators in the individual's occupational preferences. This is a pointer to the fact that career counseling is essential and may therefore enable an individual to discover occupations that 
satisfy his needs. It is also consistent with Kent and Otte (1982), who observed that, organizations interested in maximizing individual employee involvement and commitment must add career counselors in the personnel department. The finding also agrees with Gambill (1979) that it takes a professional manager to realize that time spent in career counseling may have a greater pay off in the employee's performance. Also, the result corroborate with the findings of Rabinowitz (1981), Ferri and Aranya (1983) which emphasized the interaction or "fit" of a person with his or her work situation as some determinants of organizational involvement.

The existing of a significant positive relationship between career counseling and employee commitment is explained by Gambill (1979), who opines that the employee must assume primary responsibility for his or her career development since the company cannot develop an employee who does not wish to be developed. Another explanation is given by Aplin and Gerster (1978), according to them to successfully match employee goals with organizational needs both must first be explicitly defined. And if organizations are to ascertain more explicitly their employees' career goals, personal values and priorities, they must get their information directly from employees themselves through formal counseling programmes by trained counselors.

\section{Career Opportunities and Employee} Commitment: The coefficient of correlation ( $r$ ) of 0.277 as shown in table 4 was greater than the critical $r$ value of 0.250 . This result meant that, there is a significant relationship between career opportunities and employee commitment. The finding supports the study of Barkhaus and Bulyard (1978) that, the degree of career satisfaction is directly related to the amount of congruence between the individual's perceived career needs and the opportunity that the work environment provides for meeting those needs. It equally agrees with Kent and Otte (1982) who observe a close association between career opportunities and organizational commitment and job involvement. Also Steer (1977a), Verderber, Green and Bough (1981) found positive relationship between perceived job characteristics and organizational commitment.

The presence of a positive relationship between career opportunities and employee commitment can be explained. According to Bateman and Stresser (1984), the relationship is made possible through career negotiation. It is a means of bringing employees' needs and organizational needs together.
This usually involves trade-offs that may culminate; for example in an agreement by the organization to increase career options to keep a promising employee or to accept outside professional opportunities to offset lack of internal career opportunities. This according to him includes offers of long term organizational commitments involving developmental and promotional opportunities.

Flippo (1980) further explains that an effective career development programme provides substantial employee assistance in self-diagnosis of interests, aptitudes, and capabilities. It also provides complete information concerning career opportunities within the organization. Career development programme aligns individual careers with career opportunities through a continuing programme of training, education, transfer and advancement (Nkpoyen, 2004).

\section{RECOMMENDATIONS}

On the strength of the above findings the following, recommendations are made:

1. Employers need to recognize that employees are organizations' most important assets. They should be provided with programmes for personal and career development. This entails, long range planning for career development programme including ways of securing union support.

2. Employees should be provided with information on opportunities that exist within the company for job expansion and upward mobility or expansion.

3. Employees should be given many and varied experience to enable them develops and better equips them with job related skills.

\section{CONCLUSION}

It is obvious today that employees are no longer satisfied with having just a job and the usual fringe benefits. They want a career that expresses their interests, personality, abilities and harmonies with their total situation. Their loyalty to the organization depends upon the degree to which their employees satisfy their wants. Workers commitment is a function of how effective management is able to design and implement good career development programme in the organization. Employees want management to show interest in their career development. 
Managements reward in this regard will increased workers productivity and greater commitment to the organizational goals. Understanding the trend of collective bargaining and making it suit the aim of the organization, is the premise underlying the career development approach to management. The study recommended that employers or management should place high premium on career advancement, career counseling and career opportunities of their staff.

\section{REFERENCES}

Agba, A. M. O. (2004). Teachers' perception of the impact of motivation on their job performance. Unpublished post graduate diploma thesis of the University of Calabar, Nigeria.

Aplin, J. C. \& Gerster, D. K. (1978). Career development: and integration of individual and organizational needs. Persona Journal, 55, 23-29.

Angel, H. L. \& Perry, J. L. (1981). An assessment of organizational commitment and organizational effectiveness. Administrative Science Quarterly, 26, 113.

Barkhaus, R. \& Buylyard, C. (1978). The young managercareer development: Whose responsibility? Advanced Management, 43, (3), 51 - 57.

Bateman, T. S., \& Strasser, S. (1984). A longitudinal analysis of the antecedents of organizational commitments. Academy of Management Journal, 17, $95-112$.

Becker, H. S. (1980). Notes on the concept of commitment, American Journal of Sociology, 66, 32 - 42.

Blau, G. J. (1985).The measurement and predication of career commitment. Journal Occupational Psychology, $58,277-288$.

Blau, G. J. (1986). Job involvement and organizational commitment as interactive predictors of tardiness and absenteeism. Journal of Management, 12, 577 - 584.

Blau, G. J., \& Boal, K. B. (1987). Conceptualizing how job involvement and organizational commitment affect turnover and absenteeism. Academy of Management Review, 12, 288 - 300.

Cook, J. \& Wall, T. (1980). "New work attitude measures of trust, organizational commitment and personal need nonfulfilment," journal of occupational psychology. 53, $39-52$.

Crampton, W. J., Monday, R. T., Smith, F. J., \& Porter, L. W. (1978). Early attitudes predicting future behaviours: Turnover and job performance. Paper presented at the meeting of the Academy of Management, San Francisco.

Dipboye, R. L., Smith, C. S., Howell, W. C., (1994). Understanding industrial and Organizational
Psychology: An integrated approach. Philadelphia: Harcourt Brace College Publishers.

Effiong-Fuller, E. (1996). Calabar: The concept and its evolution. Calabar: University Press.

Etzioni, A., (1975). A comparative evaluation of complex organization: On power, involvement and their correlates New Jersey: Free Press.

Ferri, S. A. \& Aranya, R. (1983). Determinants of job involvements and organizational commitment. Journal of Occupational Psychology, 14, 66-73.

Flippo, E. B. (1980). Personnel Management. Kogakusha: McGraw-Hill.

Gambill, T. R., (1979). Arrear counseling: Too little, too late? Supervisory Management, 24, 24 - 30.

Hall, D. T. (1976). Careers in Organizations. Santa Monica, Good year.

Hall, D. T. \& Schneider B., (1972). Correlates of Organizational identification as a function of career pattern and organizational type. Administrative Science Quarterly, 15, 176-189.

Hrebiniak, L. G. \& Alutto, J. (1972). Personal and Role Related Factors in the Development of Organizational Commitment. Administrative Science Quarterly, 17, 555-572.

Kent, W. E., \& Otte, F. L. (1982). Career development: the ultimate incentive. Advanced Management Journal, 47, $8-13$.

Kanter, R. M. (1980). Commitment and social organization: A study of commitment mechanisms in Utopian communities. American Sociological Review, 33, 499-517.

Leach, J. (1977). The notion and nature of career. The Personnel Administrator, 22, 31 - 37.

Leach, J. (1980). Career Development: Questions and Answer. The Personnel Administrator. 20, 30 - 37.

Lawler, E. E., III, \& Suttle, J. (1973). Expectancy theory and job behaviour. Organizational Behaviour and Human Performance, 9, 482-503.

Meyer, J. P., Paunonen, S. V., Gallatly, I. B., Goffin, R. 0., \& Jackson, D. N. (1989). Organizational commitment and job performance: It's the nature of commitment that counts.Journal of Applied Psychology, 74, 152158.

Morris, J. \& Sherman, D. (1981). Generalization of an organizational commitment model. Academy of Management Journal. 24, 512-526.

Mowday, R. T., Richard, M., Steers \& Porter, L. W. (1979). The measurement of organizational commitment. Journal of Vocational Behaviour, 14, 224 - 247. 
National Population Commission (2006). Provisional census report. Abuja: NPC.

Nkpoyen, F. J. (2003). Participative management and employee commitment in Niger Mills PLC, Calabar. Unpublished MBA Thesis of the University of Calabar, Nigeria.

Parsons, F. (1909). Choosing a Vocation. Boston; Houghton McMillan.

Porter, L. W, William, J. C. \& Smith, F. J. (1976). Organizational commitment and managerial turnover: A longitudinal study. Organizational Behaviour and Human Performance. 15, 87-98.

Peterson, R. B. \& Tracy, L. (1979). Systematic Management of Human Resources. Addison; Wesley Publishing Company.

Rabinowitz, S. (1980). Towards a developmental model of job involvement. International Review of the Applied Psychology, 46, 66-77.

Randal, D. M. (1987). Commitment and the organization: The organization man revisited. Academy of Management Journal, 12, 460-471.

Reichers, A. E. (1985). A review and reconceptualization of organizational commitment. Academy of Management

Review. 10, 465-476.
Romzek, B. S. (1989). Personal consequences of employee commitment. Academy of Management Journal, 32, 649-661.

Roe, A. (1957). Early Determinants of Vocational Choice. Journal of Counseling Psychology, 4, 212-217.

Steers, R. M. (1977a). Antecedents and Outcomes of Organizational Commitments. Administrative Science Quarterly, 22, 46-56.

Steers, R. M. (1977b). Organizational effectiveness: A behavioural view. Santa Monica. CA: Good year.

Stevens, J. M., Janice, M., \& Trice, J. (1978). Assessing personal, role and organizational predictors of managerial commitment. Academy of Management Journal, 21,380- 395.

Satump, S. \& Hartman,R.(1984). Individual exploration to organizational commitment or withdrawal. Academy of Management Journal. 27, 308 - 329.

Tiedeman, D. V. \& O'hara, R. P. (1963). Career development-choice and adjustment. New York: College Entrance Examination Board.

Verderber, R. S, Green, B. S, \& Baugh, W. (1981). Perceived job characteristics and organization commitment, Journal of Vocation Behaviour, 26, 86 103.

William, C. (1978). Human behaviour in organization. Ohio: South West Publishing. 